\title{
Alteration of Consumption Habits in Turkey Over Time
}

\author{
Mahmut Zeki Akarsu \\ Ph.D. Candidate, Warsaw University, Warsaw, Poland. \\ Email: m.akarsu@uw.edu.pl \\ Received : 2021-05-20 \\ Revised : 2021-07-08 \\ Accepted : 2021-08-22 \\ $10.46303 /$ ressat.2021.33
}

\begin{abstract}
How to cite this paper: Akarsu, M. Z. (2021). Alteration of Consumption Habits in Turkey Over Time. Research in Social Sciences and Technology, 6(3), 122-134. https://doi.org/10.46303/ressat.2021.33

This is an Open Access article distributed under the terms of the Creative Commons Attribution 4.0 International license (https://creativecommons.org/licenses/by/4.0/).
\end{abstract}

\begin{abstract}
Simon Kuznets and John Maynard Keynes did research on the subject of propensity to consume. Kuznets asserted that people do not alter their consumption/saving ratio and spend more when they have more disposable income. Keynes alleged that when disposable income increases, the rate of saving also increases over time because people tend to keep their consumption habits steady. Namely, the consumption/saving ratio of households or individuals tends to decrease as disposable income goes up. And in this study, the Keynesian consumption function is investigated in the Turkish economy. The result of this research might give insight into the future of the consumption/saving ratio in Turkey. In the study, the ARDL econometric model is operated with data from the Turkish Statistical Institute. The result of the study is that people change their consumption habits with the increase of disposable income. As a result, the consumption level has been slowing down, and the propensity to consume diminishes. That proves that the Keynesian consumption function holds in Turkey.
\end{abstract}

Keywords: Keynesian Consumption Function, Economic Growth, Average Propensity to Consume, ARDL.

JEL Classification: E12, E21, F40.

\section{Introduction}

The consumption-saving ratio is an essential indicator in the economic assessment that prefigures economic growth. Countries need savings to be able to invest in the future in order to improve the economy. Savings stimulates investment and economic growth. Besides, consumption, as well, is significant for economic growth. Keynes states that consumption spurs economic growth and prevents economic stagnation (Alper, 2018).

Consumption is a crucial economic factor of GDP. The total consumption is calculated as the sum of household consumption and public expenditure, which is of paramount importance in 
terms of its contribution to economic growth. However, savings are also essential for economic growth. Increased savings promotes the GDP in developed and developing economies (Misztal, 2011). Hence, the consumption-saving ratio is a significant indicator of economic growth.

Simon Kuznets stated that the consumption-income ratio $\left(C=b Y^{1}\right)$ would not change over time, even if people get a rise in their salary. Kuznets basically implied that people tend to save a similar percentage of their incomes (Egilmez, 2009). However, Keynes was against that theory. Keynes upheld that the average propensity to consume decreases over time when people earn more income (Arioglu \& Tuan, 2011).

The propensity to consume level is such a significant indicator to predict the future consumption-saving ratio. If people, when they have more income, tend to save more, then we can assume that economic growth will slow down, and as a consequence, policymakers should make provision for stagnation.

Economic revival is dominantly lead by consumption expenditures in Turkey (Sudi \& Ucak, 2007). In Turkey, for instance, the average propensity to consume is approximately $75 \%$. It means that Turkish consumers spend $75 \%$ of their income $(Y)$ and saves $25 \%$ of their income (Ministry of Development of the Republic of Turkey, 2018, p. 8). However, saving rates do not increase as much as they should have been because debts rather than cash mostly keep nourishing the consumption expenditures.

As shown in Figure 1, in 1998, Consumption and GDP were close to each other. Over time, as Turkey developed more, the gap between Consumption and GDP got larger. However, in Turkey, the saving rate has been diminishing, even though the GDP growth is much greater than the consumption growth (Ministry of Development, 2018). This points out borrowing for growth. Namely, Turkish economic growth is not sustainable and maintainable.

Figure 1. The graph of GDP and Consumption (in the USD) in Turkey between 1998 and 2019 (Turkish Statistical Institute, Household Consumption, 2020)

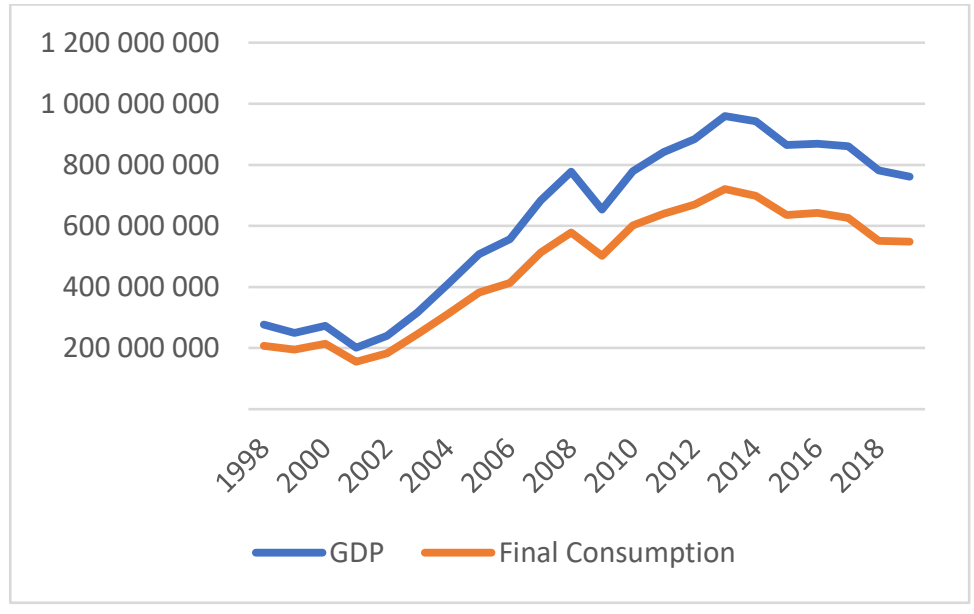

\footnotetext{
${ }^{1} \mathrm{C}$ denotes the aggregate consumption, $\mathrm{b}$ is the marginal propensity to consume, $\mathrm{Y}$ is the income (Alimi, 2013).
} 
This study aims to investigate the Keynesian consumption function in Turkey. The average propensity to consume, economic growth, consumer price index, and unemployment data are collected, which are measured in quarters between the years 1998 and 2019. Moreover, variance decomposition and the ARDL model are used to check whether Keynesian consumption theory is valid in Turkey. If the Keynesian average propensity to consume theory holds in Turkey, it might be assumed that Turkish economic growth will slow down, and households, which could be more flawed than now, might struggle with paying off debts unless Turkey changes its economic growth structure. Therefore, the result of this study will be of paramount importance in order to understand where the Turkish economy heads to.

\section{Keynesian Consumption Function}

Keynes explained in his book "General Theory of Employment, Interest, and Money." that there is a law (he) called "Psychological Law of Consumption." The law clarified that people increase their consumption when income increases. However, income earners do not increase their consumption level as much as the increasement level in income (Keynes, 1936, p. 95). He also remarked that consumption also decreases when the disposable income decreases, but not so fast (Keynes, 1936, p. 102).

$$
C=f(C h, C g)
$$

$C$ denotes Consumption, which includes dept. $C h$ is household consumption; $C g$ is government expenditure. Government expenditure and household consumption are the functions of consumption.

$$
C=\text { Ch year(quarter) }+ \text { Cg year(quarter) }
$$

(2) demonstrates that to obtain the consumption, $C h$ in $x$ year and $z$ quarter is summed with $C g$ in $x$ year and $z$ quarter. For instance, in the $1^{\text {st }}$ quarter of 1998 , household consumption was about 9 billion Turkish Liras, and government expenditure was roughly 1.4 billion Turkish Liras. The total consumption (C) was approximately 10.4 billion Turkish Liras in the $1^{\text {st }}$ quarter of 1998.

$$
C=\alpha+\phi Y, \alpha>0, \quad 0<\Phi<1
$$

$\alpha$ and $\Phi$ denote autonomous consumption and marginal propensity to consume, respectively. Autonomous consumption means that even if people do not have any income, they have to spend some amount of money to survive.

$$
A P C=C / Y=(\alpha / Y)+\Phi
$$

Average propensity to consume (APC) is calculated by consumption over income. It provides information explaining that what percentage of disposable income individuals (the whole population) tend to spend and save in a country.

If the average propensity to consume decreases when there is an increment in income, then:

$$
\triangle \text { of } A P S=\Delta(S / Y)>\Delta(C / Y)=\triangle \text { of } A P C
$$

$\Delta$ denotes increment. The increment of the average propensity to save $\Delta(S / Y)$ is greater than the increment of the average propensity to consume $\Delta(C / Y)$. In other words, Keynes asserted that when people get a rise in income, saving increases. 


\section{Literature of Propensity to Consume}

Jin (1995) searched on consumption and disposable income between OECD countries and found that consumption and disposable income are cointegrated. Sand (2002) worked on the propensity to consume Norwegian household farms. He stated that propensity to consume and propensity to save is of paramount importance since farmers, business people, and policymakers need to measure the impact on the future production level and consumption possibilities to maneuver in the coming years. Sand found out that the marginal propensity to consume is low among Norwegian farm households. Saglam² (2006) studied the Keynesian absolute income hypothesis with Turkish income data between the years 1982 and 2003. Saglam used the least square method and attained that the Keynesian theory is valid in Turkey. Slacalek (2009) analyzed the OECD countries regarding income, consumption, and wealth using the cointegration approach. The result was that there is a long-term relationship between income, consumption, and wealth. Alimi (2013) investigated how consumption is influenced by income. Alim used ordinary least squares to search the validity of the Keynesian absolute income hypothesis. Alimi found that the average propensity to consume decreases in Nigeria as income increases. Ianole \& Druıcă (2015) reached a result in the Keynesian consumption hypothesis that in Europe between the years of 2000 and 2013 and asserted that the absolute income hypothesis was valid.

Bilgili and Baglitas (2016) presented the permanent income and random walk hypotheses. They deduced that the absolute income held with the marginal propensity to consume $(0.7-0.8)$. Kim (2017) searched about the effect of consumption on economic growth in Asia, in which he obtained a result that consumption is a driving force of economic growth among Asian countries more than it is in the rest of the world. Rafiy et al. (2018) analyzed the impact of consumer spending and investment on Indonesia's economic growth using the ARDL test. They deducted that consumption fosters economic growth significantly, but investment does not. Fisher et al. (2019) used the PSID (Panel Study of Income Dynamics) dataset collected on American families. Their research, where converted measures to constant 2013 the American dollars, investigated the average propensity to consume and the marginal propensity to consume using income distributions, consumption, and wealth. They got a result that the average propensity to consume falls over time. They also found from empirical research that the bottom 10 percent has 0.8 of average propensity to consume, whilst the top 10 percent has 0.6. That means that relatively poor people save less than wealthy people since their disposable income allows them to essentials. Yigit (2020) analyzed the data to find the validity of the average propensity to consume in Turkey by using many different types of unit root tests. His result suggested that the average propensity to consume is in use.

Abeysinghe and Choy (2004) wrote an article called the aggregate consumption puzzle in Singapore and concluded that there is no cointegration relationship between income and consumption. Okcu (2008) investigated the nexus between income and consumption using the

\footnotetext{
2 Saglam (2006) used the least square econometric model and covered the year between 1982 and 2003 when Turkey faced high inflation, and purchasing power sank dramatically. In this study, I covered the years between 1998 and 2019, when the Turkish economy boosted and the inflation rate went down. Therefore, the data, which covers steady inflation time, could provide more reliable results on this topic.
} 
cointegration analysis in Turkey and found no relationship between consumption function and income function.

Most of the researches certify that the Keynesian consumption function is valid in many different countries. As seen above, scholars use many different methodological approaches in order to sift through the hypothesis.

\section{Discussion}

In this research, the validity of the Keynesian theory of the average propensity to consume will be checked using the ARDL econometrics model in Turkey between the years 1998 and 2019. The variables, which are the average propensity to consume, Gross Domestic Product (GDP) ${ }^{3}$ by expenditure in constant price $(2015=100)$ data, Unemployment data (person) ${ }^{4}$, and consumer price index (\%) data, are collected to conduct the empirical research from Turkish Statistical Institution. All of the data is quarterly and Variance Decomposition, VAR Bound Test, and Error Correction Form are used in the empirical research part.

Consumption includes household consumption and government expenditure (2). $C / Y$ denotes consumption divided by gross domestic product $(\mathrm{Y})$. The consumer price index is INF; the gross domestic product is GDP; Unemployment is UNEMP. C/Y had a strong seasonality due to the quarterly data. To avoid the seasonality problem, $C / Y$ is seasonally adjusted, using "Seasonal and Trend decomposition using Loess" (STL), before starting the econometric analysis.

Figure 2 illustrates the graph of $C / Y$ (seasonally adjusted), GDP, Inf, and Unemp. As can be seen, the gross domestic product has increased sharply since 1998, while the consumer price index remains around 3\% (quarterly). In Turkey, roughly 4 million people were unemployed in 2019, which is the highest unemployment in history (Turkish Statistical Institute, Turkish Statistical Institute Unemployment, 2020).

Augmented Dickey-Fuller unit root test is performed for all variables. All of the variables were nonstationary in level and became stationary in $1^{\text {st }}$ difference (Appendix Table $1 \mathrm{~A}$ ). It means all of the variables are dynamic. After the unit root test, the Johansen cointegration test (intercept (no trend) in CE and test VAR) is applied to examine if the variables are cointegrated. Test results revealed a cointegration among variables, and variables have long-run relationships (Appendix Table 2A).

Before the subsequent econometric analysis, we take the logarithm of gross domestic product and unemployment since they are collected to interpret data efficiently. LNGDP denotes the

\footnotetext{
3 In this research, Gross Domestic Product (GDP) data is used instead of the GDP per capita data because GDP per capita is related to economic growth as well as population growth. In consumption function theory, we do not consider population growth. Therefore, using GDP per capita could slightly change the result. So, I did not use GDP per capita.

4 In this research, Unemployment data is collected in person instead of in the rate because Turkey has a chronic unemployment issue, which is around $10 \%$. The unemployment rate does not frankly explain how big unemployment is in Turkey, and when the unemployment rate is implemented, the result becomes very unreliable due to the using unemployment rate instead of unemployment in the number of people. With unemployment in the number of people, we can see the changes of unemployment over time, and it helps us understand the whose saving increase, which influences the theory.
} 
logarithm of the gross domestic product; LNUNEMP denotes the logarithm of unemployment. Besides, we also take the first difference of all of the variables since they are nonstationary.

Figure 2. The graph of Consumption/GDP, GDP, consumer price index, and unemployment
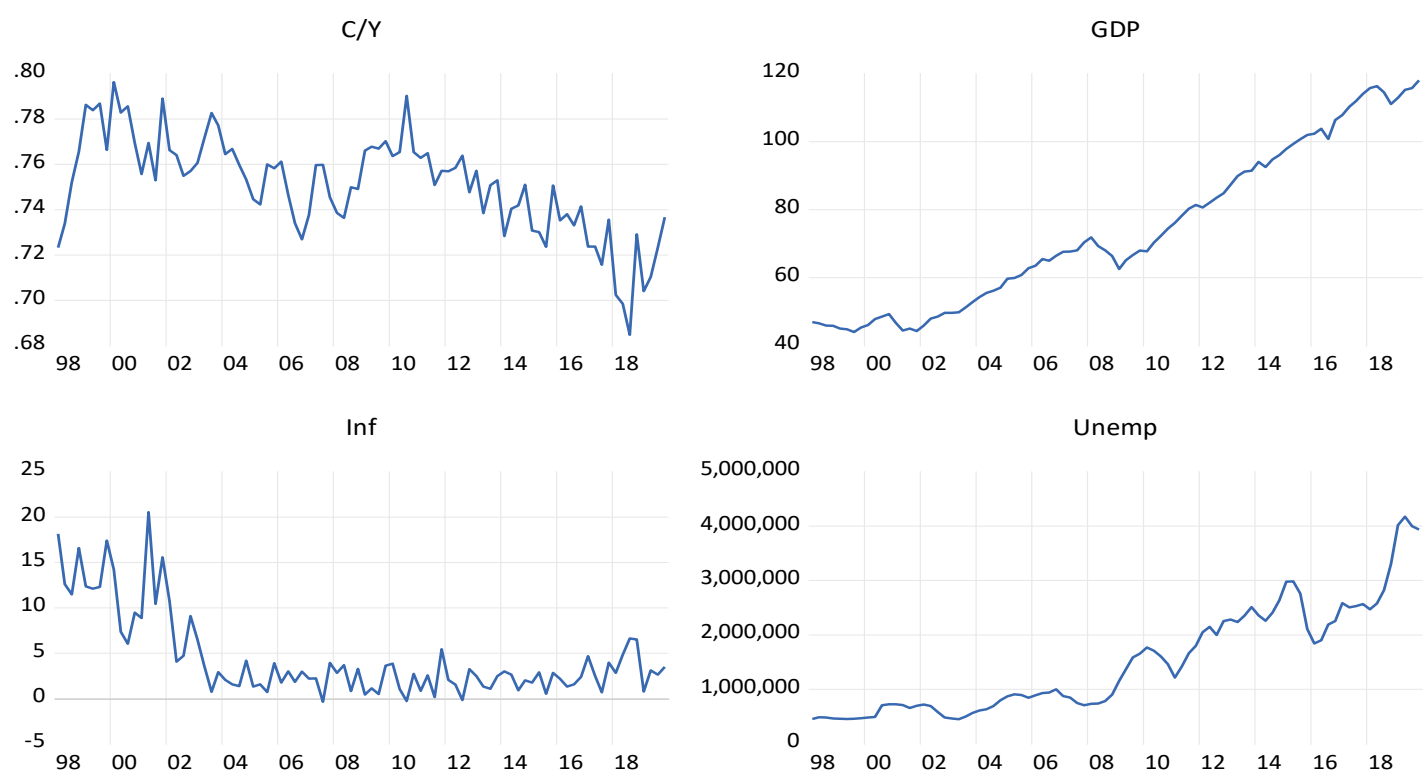

Figure 3. Inverse Root of AR Characteristic Polynomial, between -1 and +1 .

\section{Inverse Roots of AR Characteristic Polynomial}

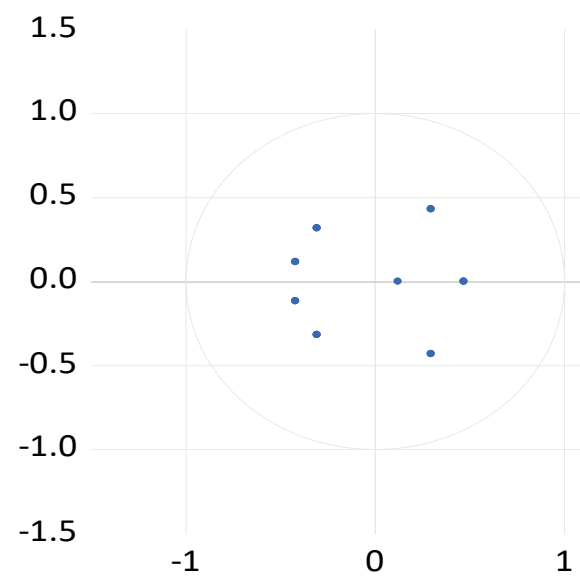

Inverse Root of AR Characteristic Polynomial Roots is used to check whether the model is stationary and invertible (Brooks, 2019). As seen in Figure 3, roots lie inside the unit circle, which means that our VAR model is steady, and any shock will die out in the long run. This test is vital to prove that our model is valid and that the result is acceptable.

Stacked graphs of Variance Decomposition demonstrate in Figure 4 that $C / Y$ has mainly explained itself, yet in the long run (88.81\%), it is influenced by the consumer price index (5.26\%), and gross domestic product (3.39\%), and unemployment (2.53\%) in 10 periods of time. The gross domestic product also mostly explained itself in the long run, but from the second 
period to the tenth period, $\mathrm{C} / \mathrm{Y}$ affected the GDP by about $8.90 \%$, which means consumption has an impact on GDP, and unemployment, otherwise, has a weak impact on GDP, which is $3.92 \%$ in the tenth period. Inflation is almost no impact on GDP (0.26\%).

Figure 4. Result of Variance Decomposition.

Variance Decomposition using Cholesky (d.f. adjusted) Factors
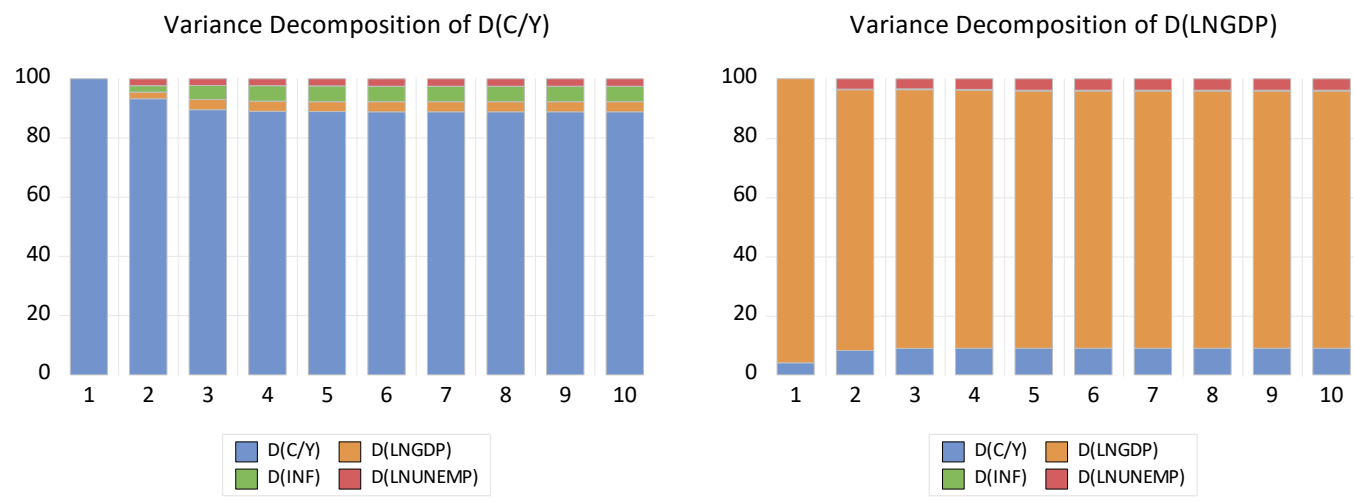

Variance Decomposition of $\mathrm{D}(\mathrm{INF})$
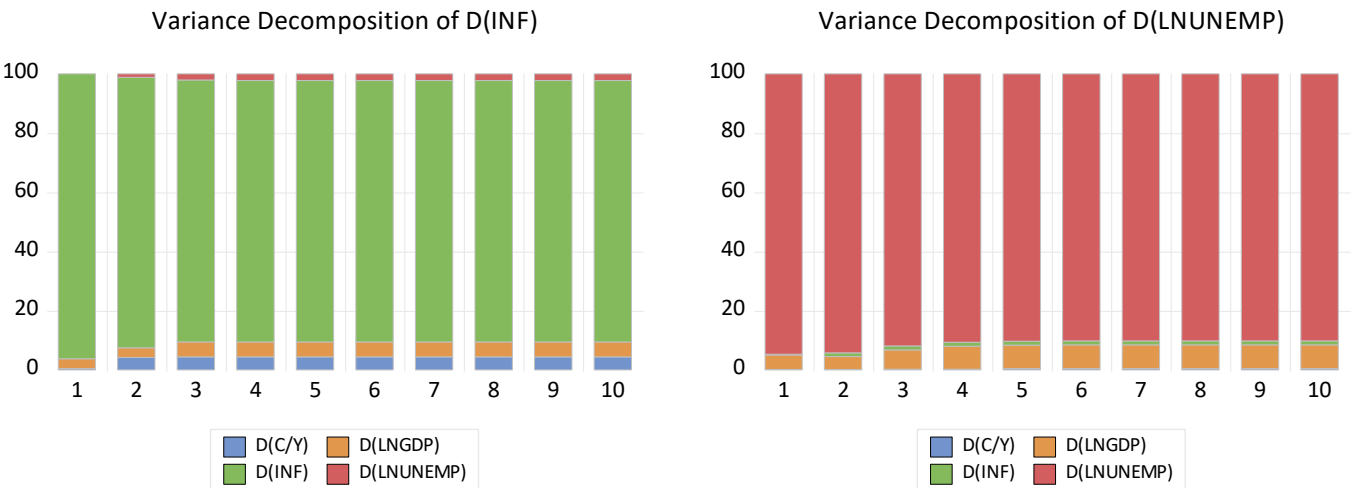

Inflation is explained by itself and the other three variables. In the tenth period, inflation accounted for itself by $88.12 \%$, while $\mathrm{C} / \mathrm{Y}, \mathrm{GDP}$, and unemployment accounted for inflation by $4.35 \%, 5.03 \%, 2.26 \%$, respectively. Namely, inflation is influenced by those three variables, even though they are not a substantial impact on inflation. Unemployment is mostly accounted for itself by $94 \%$ in the first period and $90 \%$ points in the tenth period. However, gross domestic product explains unemployment at $4.90 \%$ in the first period and $8.01 \%$ in the tenth period.

In short, variance decomposition illustrates that consumption is a crucial economic factor for GDP growth. Inflation influences consumption negatively due to the fact that in an inflationary economic condition, people lose purchasing power. In this case, even if inflation does not influence GDP directly, inflation has an impact on GDP through consumption. Moreover, to decrease unemployment, Turkey should increase economic growth as a consequence of variance decomposition. Variance decomposition demonstrates that $C / Y$ and GDP have an quite strong nexus. 
Table 1. ARDL Long Run Form and Bounds.

\begin{tabular}{|c|c|c|c|c|}
\hline \multicolumn{5}{|c|}{ ARDL Long Run Form and Bounds } \\
\hline Variable & Coefficient & Std. Error & T-statistic & Prob. \\
\hline LNGDP & -0.090101 & 0.022714 & -3.966738 & $0.0002^{*}$ \\
\hline LNUNEMP & 0.016491 & 0.010208 & 1.615541 & 0.1102 \\
\hline INF & -0.000400 & 0.000674 & -0.592883 & 0.5550 \\
\hline C & 0.906036 & 0.067580 & 13.40687 & $0.0000^{*}$ \\
\hline $\begin{array}{c}\text { F-Bounds } \\
\text { Test }\end{array}$ & & & & \\
\hline Test Statistic & Value & Signif. & I(0) & I(1) \\
\hline F-statistic & 5.329440 & $10 \%$ & 2.37 & 3.2 \\
\hline k & 3 & $5 \%$ & 2.79 & 3.67 \\
\hline & & $2.5 \%$ & 3.15 & 4.08 \\
\hline & & $1 \%$ & 3.65 & 4.66 \\
\hline
\end{tabular}

Note: Dependent Variable: $D(C / Y)$, Selected Model: $\operatorname{ARDL}(3,0,0,0), *$ is $p<0,01$.

In the model, we did not encounter any heteroskedasticity, autocorrelation, normality problems (Appendix Table 3A, Table 4A, Figure 1A). Lastly, the Cusum test and Cusum of squares test are between lines of $5 \%$ significance, which means that the model does not have any issue (Appendix Figure 2A and 3A).

ARDL long-run form and bounds test helps find the long-run relationship between variables. $\mathrm{C} / \mathrm{Y}$ is the dependent variable in our model, and the logarithm of gross domestic product, the logarithm of unemployment, and the consumer price index are independent variables. The Fbound test confirms that between variables, there is a long-run relationship. Subsequently, as seen in the selected model ARDL $(3,0,0,0)$, unemployment and consumer price index are statistically non-significant, yet the gross domestic product is statistically significant, and when GDP is on the increase by $1 \%, C / Y$ slightly drops.

\section{Concluding Remark}

GDP, consumer price index (inflation), and unemployment impact the average propensity to consume $(C / Y)$. Inflation is the most significant influencer of $C / Y$. After inflation, GDP is the second most significant influencer of $C / Y$. On the other hand, $C / Y$ has a substantial impression on GDP, which means that consumption is a driving force for economic growth.

ARDL long-run form and bound test illustrate that when GDP increases, the average propensity to consume falls in the long run. It means that the Keynesian consumption function holds in Turkey. Namely, during the Turkish economic growth, people spend less than the increase in income and save more.

As known, unemployment in Turkey has increased dramatically, and approximately 4.5 million people are out of work. But meanwhile, disposable income increased, and people raised their savings. That means that the high-income group is the capital power holder earning more and more in time and saves more and more. Namely, the Keynesian consumption function does not 
Akarsu, M. Z., Alteration of Consumption Habits in Turkey Over Time

clarify the behavior of the whole society. Instead, it explains the behavior of the big capital holders. If there had been the income group consumption rate dataset, the result would have been more reliable and accurate about which income group saves and spends mainly.

Moreover, the Consumption/GDP ratio is slowly dropping, but the saving rate is not increasing. Because Turkish people consume goods and services with disposable income and loans, that means loans enhance people's disposable income. It is also visible in the household debt. Household debt has risen significantly over time in Turkey (OECD, 2021, p. 34). Namely, consumption and economic growth are dominantly driven by loans, which means the economic growth and consumption take place with the massive debt cycle in Turkey.

Another finding during the research is that the Keynesian consumption function does not take income distribution or poverty into account. That is the biggest obstacle in this theory since we do not know what part of society influences consumption primarily. Furthermore, the GINI coefficient is relatively high in Turkey (41.9, source: FRED, 2019), and millions of people are out of work as the saving rate is increasing. That means that in Turkey, consumption and saving are driven by wealthy people. In the future, research, which is similar to Fisher et al. (2019), might be conducted to analyze the different income groups in order to observe which income groups drive consumption.

To sum up, as long as the economic growth of Turkey keeps growing in the same way, the driving force of consumption on economic growth will decrease. The diminishing average propensity to consume causes economic growth to slow down. As a consequence of reducing consumption, the dept cycle could be broken, and people and institutions could not pay off debt. Therefore, Turkey should get to switch its economic growth structure from consumptionbased economic growth to aggressive export-based. Turkish domestic market is not a genuine driving force for economic growth. Turkey should improve the exportable goods market and concentrate on Research and Development (R\&D).

\section{References}

Abeysinghe, T., \& Choy, K. M. (2004). The aggregate consumption puzzle in Singapore. Journal of Asian Economics, 15(3), 563-578. Retrieved from https://scholarbank.nus.edu.sg/handle/10635/19983

Alimi, R. S. (2013). Keynes' Absolute Income Hypothesis. Munich Personal RePEc Archive, MPRA Paper No. 49310, Online at https://mpra.ub.uni-muenchen.de/49310/.

Alper, A. E. (2018). The Relationship of Economic Growth With Consumption, Investment, Unemployment Rates, Saving Rates and Portfolio Investments In The Developing Countries. Gaziantep University Journal of Social Sciences, 17(3), 980-987.

Arioglu, E., \& Tuan, K. (2011). Test of the Absolute Income Hypothesis in USA And Europe. Journal of Institute of Soical Sciences of University of Cukurova, 20(2), 299 - 316.

Bilgili, F., \& Baglitas, H. H. (2016). Testing the Permanent Income and Random Walk Hypotheses for Turkey. International Journal of Economics and Financial Issue, 6(4), 1371 - 1378. Retrieved from http: www.econjournals.com

Brooks, C. (2019). EViews Guide for Introductory Econometrics for Finance. Cambridge: Cambridge University Press.

Egilmez, M. (2009). Macroeconomics. Istanbul: Remzi Publising House. 
Akarsu, M. Z., Alteration of Consumption Habits in Turkey Over Time

Fisher, J., Johnson, D., Smeeding, T., \& Thompson, J. (2019). Estimating the Marginal Propensity to Consume Using the Distributions of Income, Consumption and Wealth. Federal Reserve Bank of Boston (working paper), No: 19-4.

FRED (2019). GINI Index for Turkey. Retrieved from FRED Economic Data: https://fred.stlouisfed.org/series/SIPOVGINITUR

lanole, R., \& Druıcă, E. (2015). Testing the Keynesian consumption hypothesis on European panel data. Revista Romana de Economie, 40(1), 49 - 71. Retrieved from http://www.revecon.ro/articles/2015-1/2015-1-2.pdf

Jin, F. (1995). Cointegration of consumption and disposable income: Evidence from twelve OECD countries. Southern Economic Association, 62, 77-88. Retrieved from http://www.jstor.org/stable/pdfplus/1061377.pdf

Keynes, J. M. (1936). The General Theory of Employment, Interest, and Money. Cambridge: Palgrave Macmillan.

Kim, H. (2017). The Effect of Consumption on Economic Growth in Asia. Journal of Global Economics, 5(3), 1-8.

Ministry of Development. (2018). 11th Development Plan (2019 - 2023). Ankara: Ministry of Development. Retrieved from https://www.sbb.gov.tr/wpcontent/uploads/2020/04/Tuketim_ve_TasarrufEgilimleriOzellhtisasKomisyonuRaporu .pdf

Ministry of Development of the Republic of Turkey. (2018). 11th Development Plan. Ankara: Ministry of Development.

Misztal, P. (2011). The Relationship Between Savings and Economic Growth in Countries with Different Level of Economic Development. Financial Internet Quaterly, 14(3), 17-29.

OECD. (2021). OECD Economic Surveys: Turkey. OECD. Retrieved from https://www.oecd.org/economy/turkey-economic-snapshot/

Okcu, A. B. (2008). Examining of Income-Consumption's Relationship with Cointegration Analyses for Turkey. Unpublished Master Thesis. Adana: Cukurova University. Retrieved from http://libratez.cu.edu.tr/tezler/7109.pdf

Rafiy, M., Adam, P., Bachmid, G., \& Saenong, Z. (2018). An Analysis of the Effect of Consumption Spending and Investment on Indonesia's Economic Growth. Iranian Economic Review, 22(3), 753 - 766.

Saglam, Y. (2014). Keynesian Consumption Function: Case of Turkey. Journal of Institute of Social Science of Mustafa Kemal University, 3(6).

Sand, R. (2002). The Propensity to Consume Income from Different Sources and Implications for Saving: an Application to Norwegian Farm Households. Workshop on the Farm Household-Firm Unit: Its importance in agriculture and implications for statistics, https://core.ac.uk/download/pdf/6407984.pdf.

Slacalek, J. (2004). International Evidence on Cointegration between Consumption, Income, and Wealth. Unpublished manuscript, 1 - 25. Retrieved from http://www.slacalek.com/research/sla04cointCAY/sla04cointCAY.pdf

Sudi, A., \& Ucak, A. (2007). Meaningfulness of Economic Growth and Development: A Study on Turkish Economy. The Journal of Accounting and Finance, 34, 57-65. Retrieved from https://dergipark.org.tr/tr/pub/mufad/issue/35603/395513

Turkish Statistical Institute. (2020). Household Consumption. Retrieved from https://data.tuik.gov.tr/Bulten/Index?p=Hanehalki-Tuketim-Harcamasi-2019-33593 
Turkish Statistical Institute. (2020). Turkish Statistical Institute Unemployment. Retrieved 12 19, 2020, from https://data.tuik.gov.tr/Kategori/GetKategori?p=istihdam-issizlik-veucret-108\&dil=1

Yigit, M. (2020). Testing the validity of absolute income hypothesis through average propensity to consume for Turkish economy. In S. A. Hatirli, O. Demirel, \& S. A. Koc, Theoretical and Applied Studies on Turkish Economy Vol. I (pp. 105-120). London: IJOPEC Publication Limited.

\section{Appendix}

Table 1A. Augmented Dickey-Fuller Unit Root Test

\begin{tabular}{|c|c|c|c|}
\hline Variables & Test & I(0) Prob. & I(1) Prob. \\
\hline C/Y & ADF & 0.1736 & 0.0001 \\
\hline GDP & ADF & 0.9993 & 0.0000 \\
\hline Inf & ADF & 0.1352 & 0.0000 \\
\hline Unemp & ADF & 0.8833 & 0.0000 \\
\hline
\end{tabular}

Table 2A. Johansen Cointegration Test

\begin{tabular}{|c|c|c|c|c|}
\hline \multicolumn{5}{|c|}{ Unrestricted Cointegration Rank Test (Trace) } \\
\hline $\begin{array}{c}\text { Hypothesize } \\
d \text { No. of } \\
\text { CE(s) }\end{array}$ & Eigenvalue & $\begin{array}{c}\text { Trace } \\
\text { Statistic }\end{array}$ & $\begin{array}{c}0.05 \text { Critical } \\
\text { Value }\end{array}$ & Prob.** \\
\hline None* & 0.285764 & 54.58934 & 47.85613 & 0.0102 \\
\hline At most 1 & 0.169892 & 25.98332 & 29.79707 & 0.1292 \\
\hline At most 2 & 0.097308 & 10.15637 & 15.49471 & 0.2689 \\
\hline At most 3 & 0.016967 & 1.454597 & 3.841465 & 0.2278 \\
\hline \multicolumn{5}{|c|}{ Trace test indicates 1 cointegrating eqn(s) at the 0.05 level } \\
\hline \multicolumn{5}{|c|}{${ }^{*}$ denotes rejection of the hypothesis at the 0.05 level } \\
\hline \multicolumn{5}{|c|}{ **MacKinnon-Haug-Michelis (1999) p-values } \\
\hline \multicolumn{5}{|c|}{ Unrestricted Cointegration Rank Test (Maximum Eigenvalue) } \\
\hline $\begin{array}{c}\text { Hypothesize } \\
d \text { No. of } \\
\text { CE(s) }\end{array}$ & Eigenvalue & $\begin{array}{c}\text { Trace } \\
\text { Statistic }\end{array}$ & $\begin{array}{c}0.05 \text { Critical } \\
\text { Value }\end{array}$ & Prob.** \\
\hline None* & 0.285764 & 28.60603 & 27.58434 & 0.0369 \\
\hline At most 1 & 0.169892 & 15.82695 & 21.13162 & 0.2351 \\
\hline At most 2 & 0.097308 & 8.701773 & 14.26460 & 0.3118 \\
\hline At most 3 & 0.016967 & 1.454597 & 3.841465 & 0.2278 \\
\hline \multicolumn{5}{|c|}{ Max-eigenvalue test indicates 1 cointegrating eqn(s) at the 0.05 level } \\
\hline \multicolumn{5}{|c|}{ * denotes rejection of the hypothesis at the 0.05 level } \\
\hline **MacKinnon- & ( & 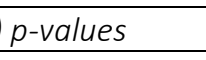 & & \\
\hline
\end{tabular}


Table 3A. Result of Heteroskedasticity.

Heteroskedasticity Test: Breusch-Pagan-Godfrey

Null hypothesis: Homoskedasticity

\begin{tabular}{llll} 
F-statistic & 1.451438 & Prob. F(10,73) & 0.1756 \\
Obs*R-squared & 13.93151 & Prob. Chi-Square(10) & 0.1761 \\
Scaled explained SS & 9.052231 & Prob. Chi-Square(10) & 0.5272 \\
\hline \hline
\end{tabular}

Table 4A. Result of Autocorrelation test.

Breusch-Godfrey Serial Correlation LM Test:

Null hypothesis: No serial correlation at up to 2 lags

\begin{tabular}{llll}
\hline \hline F-statistic & 1.288301 & Prob. F(2,71) & 0.2821 \\
Obs*R-squared & 2.941622 & Prob. Chi-Square(2) & 0.2297 \\
\hline \hline
\end{tabular}

Figure 1A. Result of Normality test.

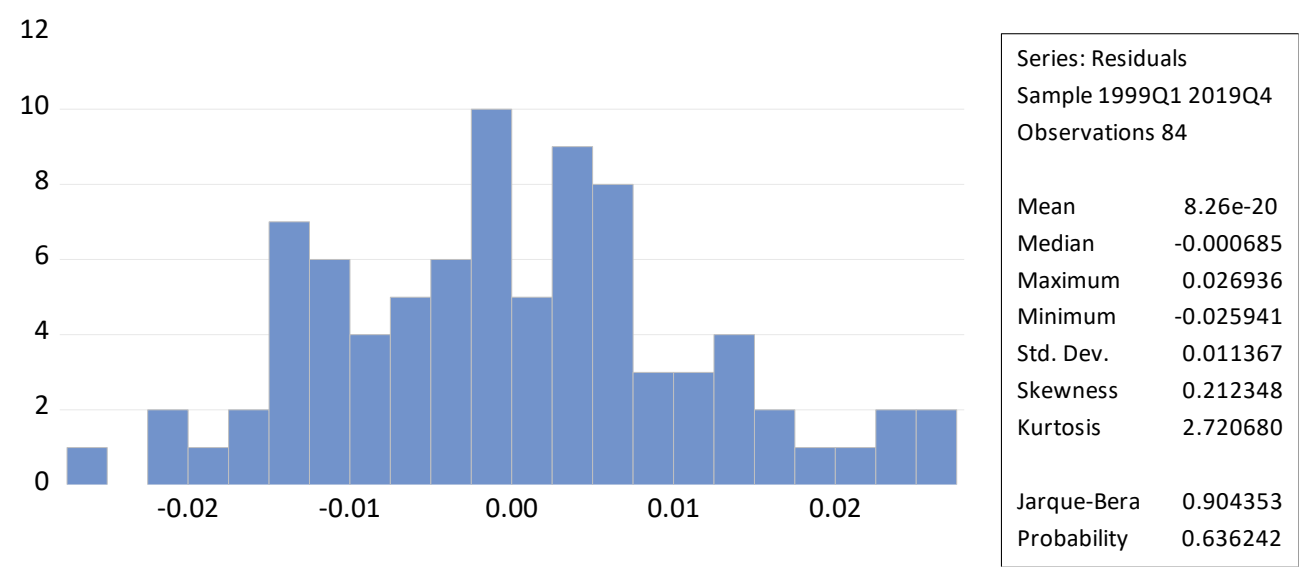


Figure 2A. Result of Cusum test.

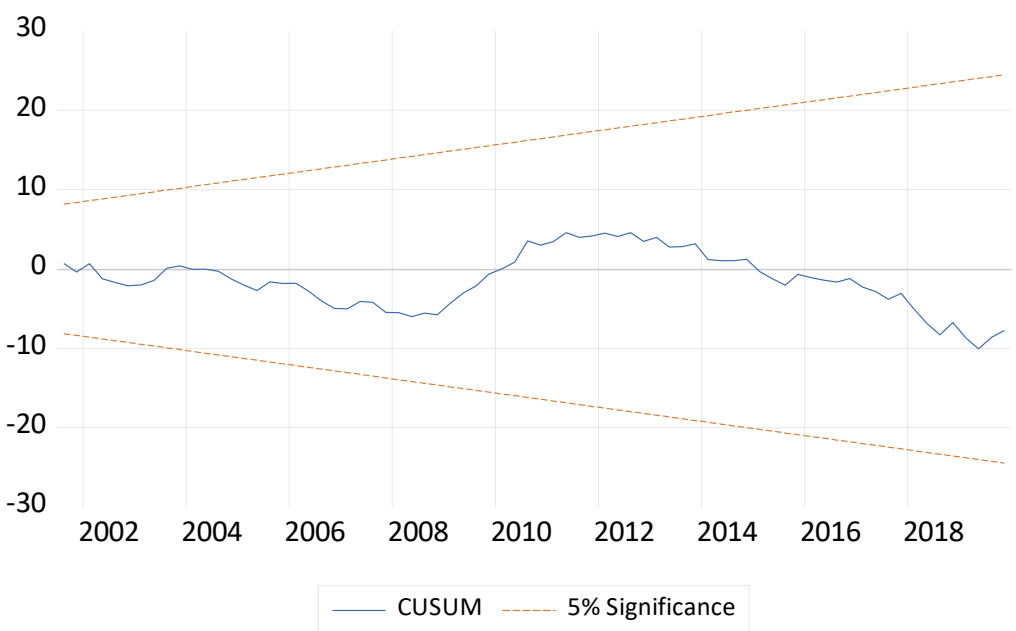

Figure 3A. Result of Cusum of squares test.

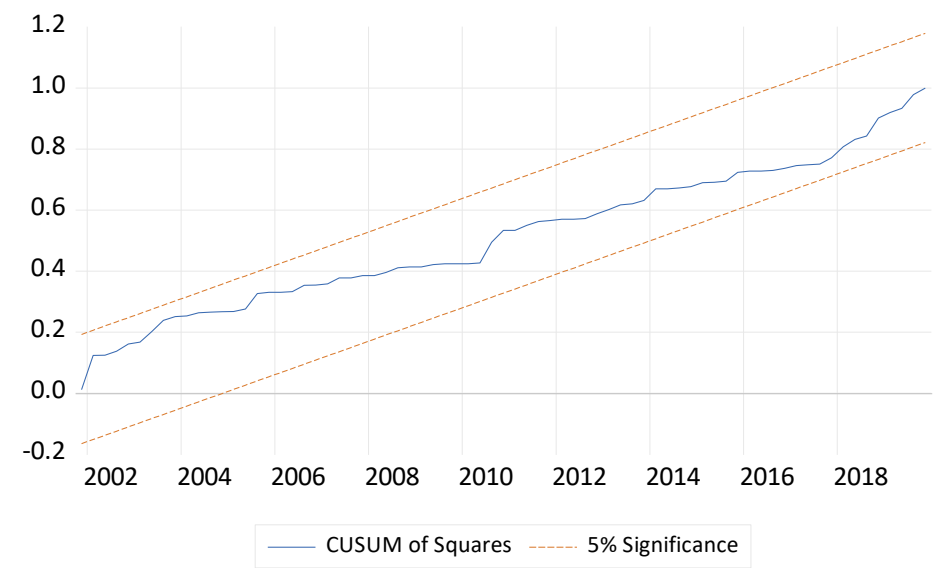

